\title{
EFFECT OF SACCHAROMYCES CEREVISIAE FEED SUPPLEMENTATION ON HAEMATOLOGY AND REPRODUCTIVE PARAMETERS FOR ALGERIAN RABBITS
}

\author{
Omar BESSEBOUA ${ }^{1, *}$, Abdelhanine AYAD ${ }^{2}$ \\ *E-mail: besseboua.omar@gmail.com
}

Received: Feb. 10, 2021. Revised: May, 20, 2021. Accepted: June 10, 2021. Published online: June 22, 2021

\begin{abstract}
This study aims at investigating the effect of Saccharomyces cerevisiae (SC) supplementation on reproductive performance, haematological parameters and fertility of rabbits under Algerian conditions. The animals were divided into three groups and received the same feed ration during the experimental period. The control group received a basal diet without feed additives (Group\#0) and the two yeast $\mathrm{SC}$ groups received 0.3 and $0.6 \mathrm{~g}$ /day per head (Group\#1 and Group\#2, respectively). Semen and blood samples were collected for determination of semen parameters and haematology. The weights of rabbits treated with SC $0.3 \mathrm{~g}$ /day were statistically significantly different $(P<$ 0.05 ) from the control groups and group treated with SC $0.6 \mathrm{~g} /$ day. There were significant differences between the treatment groups for (RBCs), haemoglobin (HGB), haematocrit (HCT) and mean corpuscular haemoglobin $(\mathrm{MCH})$ values,
\end{abstract}

with higher values in rabbits supplemented with SC $0.3 \mathrm{~g} /$ day and $0.6 \mathrm{~g} /$ day, compared to those in the control group. The scrotal diameter did not differ between the dietary treatments. When compared with the control group, feeding rabbits graded levels of SC resulted in an increase in the average semen volume, mass motility and individual motility at day 51 of the experiment. On the other hand, the sperm concentration was significantly lower $(P<0.05)$ in rabbits supplemented with SC $0.3 \mathrm{~g} /$ day and $0.6 \mathrm{~g} /$ day during the two months compared to that in the control group. The spermatozoa mortality rate was lower for the rabbits supplemented with $\mathrm{SC}$ $0.3 \mathrm{~g} /$ day and $0.6 \mathrm{~g} /$ day $(15.7 \%$ and $11.4 \%$, respectively), compared to that in the control group (24\%). In conclusion, this study has shown that inclusion of SC $0.3 \mathrm{~g} /$ day and $0.6 \mathrm{~g} /$ day in the diets of rabbit has positive effects on body weight

\footnotetext{
1 Department of Agronomic and Biotechnological Sciences, Faculty of Nature and Life Sciences, University $\mathrm{H}$. Benbouali, 02000, Chlef, Algeria

2 Department of Environment and Biological Sciences, Faculty of Nature and Life Sciences, University of Bejaia, 06000, Bejaia, Algeria
} 


\section{Omar BESSEBOUA, Abdelhanine AYAD}

and sperm analysis. Moreover, it increases the level (RBCs), haemoglobin (HGB), haematocrit (HCT) and mean corpuscular haemoglobin $(\mathrm{MCH})$.

Keywords: Saccharomyces cerevisiae; feed; haematological parameters; sperm; rabbits.

\section{INTRODUCTION}

It is known that high levels of antibiotics have been used in foodproducing animals as growth promoters and for disease prophylaxis. However, there is a major problem among human consumers due to the occurrence of antibiotic residues in meat because of the wide use of antibiotics and antibiotic-resistant bacteria in animals. Therefore, the European Union Commission banned the use of antibiotics as a growth enhancer in the diets of animals (Castanon, 2007). It is therefore imperative to replace the overuse of antibiotics and to search for a new safe alternative for health improvement and infection control in animals.

The probiotics (bacterial and yeast cultures) are non-pathogenic microbial adjuncts, which have been used as feed supplements and also as growth promoters, improving the immune system of animals by promoting the composition and microbial balance in its gut. Several studies have garnered attention over the years on the use of probiotics as alternative feed additives in order to replace antibiotics and synthetic chemical feed supplements (Higginbotham and Bath, 1993; Brydt et al., 1995; Sumeghy, 1995;
Strzetelski, 1996). Yeasts are being widely used in food, medicine and the cosmetic industry due to their bioactive and nutritional components, such as peptides, amino acids, beta-glucan, glutathione, cerebroside and zinc (Cha et al., 2004, 2008; Kinosita et al., 2007; Lee et al., 2005).

Moreover, it increases the level of some haematological parameters, such as RBCs, HGB, HCT, and GCTs. There has been scientific interest over the last two decades in the supplement Saccharomyces cerevisiae (SC), which increases the cellulolytic rumen bacteria (Ogunade et al., 2019). Pinheiro et al. (2020) and Arif et al. (2020) reported that the strains of SC have potential as probiotics and are adsorbent of aflatoxin B1. The Algerian rabbit represents a significant portion of the agricultural economy. The statistical data revealed that more and more breeders are interested in rabbit farms where the production of rabbit meat is the first activity (Saidj et al., 2013). Rabbit meat is an important source of protein, rich in precious nutrients (essentially amino acids and lipids and low in fat content and cholesterol $(<59 \mathrm{mg} / 100 \mathrm{~g})$ (Combes and Dalle Zotte, 2005). In the last years, the Algerian Department of Agriculture has adopted a policy of diversifying animal production by encouraging rabbit farmers to invest more. Therefore, this research study was conducted to explore the impact of SC supplementation on some reproductive parameters and haematological balance in male rabbits under Algerian conditions. It is known 


\section{EFFECT OF YEAST ON SPERM RABBITS}

that high levels of antibiotics have been used in food-producing animals as growth promoters and for disease prophylaxis.

\section{MATERIALS AND METHODS}

With regard to the ethical aspects, this experimental procedure was approved by the Scientific Committee at the University of Chlef (Report of Faculty Scientific Council \#04 dated 30 September 2015).

\section{Animal groups and feeding}

The experiment was conducted in an experimental farm of the Department of Agronomic and Biotechnological Sciences $\left(36^{\circ} 10^{\prime} \mathrm{N}, 1^{\circ} 19^{\prime} \mathrm{E}\right.$; University of Chlef, Algeria). This study was conducted from 1 March 2016 to 30 April 2016. A total of nine rabbits aged 10 months were used for this study. The rabbits were in a good condition during the experimental period. The animals were divided into three groups and received the same feed ration during the experimental period. Before the beginning of the feeding experiment, the pre-trial period consisted of an adaptation period of two weeks for animals who were fed SC supplementation. Then, the rabbits were followed over six weeks, during which the collection and analysis of sperm were performed.

The animals were divided into three groups and received the same feed ration during the experimental period. The control group received a basal diet without feed additives (Group\#0), and the two yeast $\mathrm{SC}$ groups received $0.3 \mathrm{~g} /$ day and $0.6 \mathrm{~g} / \mathrm{day}$ per head (Group\#1 and Group\#2, respectively). The supplemented SC (CNCM I-1077, Lallemand Animal Nutrition) is marketed by the Vetam Company (Mostaganem, Algeria) and contains $20 \times 10^{9} \mathrm{CFU} / \mathrm{g}$ of live yeast. The water was distributed ad libitum for the study period. The rabbits were weighted at the start of the experiment and then on the following days 1, 15, 29, 44 and 51 . Weight gain (WG) was calculated as follows: $\mathrm{DWG}(\mathrm{g} /$ day $)=($ Final weight Initial weight).

\section{Blood and semen sampling}

Whole blood samples were withdrawn from the marginal vein into EDTA tubes for haematological analysis. Haematological indices, such as red blood cells (RBCs), platelets (PLTs), haemoglobin (HGB), white blood cells (WBCs), lymphocytes (LCTs), monocytes (MCTs), granulocytes (GCTs), haematocrit (HCT), mean corpuscular volume (MCV), mean corpuscular haemoglobin $(\mathrm{MCH})$, mean corpuscular haemoglobin concentration (MCHC) and red blood cell distribution index (RBDI), were measured. All these measurements were performed using an automated haematology analyser (SWELAB alfa, Boule Medical AB, Spanga, Sweden).

The semen was collected on days 21 , 35 , and 42 to analyse the various parameters of spermatozoa. The collected semen was transported quickly to the laboratory and kept at body temperature. The study protocols of the semen preparation and analysis were done according to Wyrobek and Bruce (1975). The volume of semen was simply measured using the graduations on the collection tube. The $\mathrm{pH}$ was measured with a digital $\mathrm{pH}$ meter. Sperm motility was estimated after semen collection by examining a small drop of semen placed on a warm slide and examined by light microscope. Sperm concentration was determined using a Thoma cell counting chamber. The determination of live and dead sperm cells was analysed using the eosin-nigrosin staining procedure according to Esteso et al. (2006). 


\section{Omar BESSEBOUA, Abdelhanine AYAD}

Scrotal diameter was measured at the widest point of the scrotum with a graduated tape on days 14 and 45. Sexual activity (libido) was estimated by the time between introduction of the female into the male's cage and ejaculation. At the end of the experiment, the sexual behaviour of rabbit bucks was determined. A sexually receptive female was then dropped from one side of the chamber and allowed 30 min of stimulation (Sanna et al., 2015; Cicero et al., 2001). Mounting latency (ML) was estimated as time from female introduction into the cage to the occurrence of first mount. The intromission latency was defined as the duration interval between the introduction of the female and intromission by the male (Dabhakar and Zade, 2013; Pare et al., 2014; Mutwedu et al., 2019).

\section{Statistical analyses}

Statistical analyses of the results were carried out in Statview (Version 4.55). Statistical analysis was performed using t-tests to compare between different groups. The data were expressed as mean $\pm \mathrm{SE}$ and $P<0.05$ was considered significant.

\section{RESULTS}

The final body weight of the rabbits fed different levels of treatment are presented in Table 1. The weights of rabbits treated with SC $0.3 \mathrm{~g} /$ day were significantly decreased $(P<0.05)$, compared to the group control and group treated with SC $0.6 \mathrm{~g} /$ day.

At the end of the experiment (day 51), the rabbits supplemented with graduated levels of SC had a slightly lower body weight than the control group $(3.282 \mathrm{~kg})$. Also, the rabbits supplemented with SC 0.3 g/day showed a continuous increase in body weight, as compared to the other groups.

The mean $\pm \mathrm{SE}$ values of the blood parameters of treated and nontreated rabbits is shown in Table 2. There were significant differences between the treated groups for RBCs, HGB, HCT and MCH values, with higher values in rabbits supplemented with SC $0.3 \mathrm{~g} /$ day and $0.6 \mathrm{~g} /$ day, compared to the control group. PLT, WBCs and GCTs for the control group were higher than the treated groups. On the other hand, MCTs and LCTs were low in the control group compared to those in the treated groups, which was statistically insignificant $(P>\quad 0.05)$. Rabbits supplemented with SC showed slightly higher values in $h$ haematological parameters, such as MCV and RBDI, compared to those reported for the control group.

The effect of SC supplementation on the scrotal diameter, sexual behaviour and sperm analysis of the rabbits is illustrated in Table 3. The scrotal diameter did not differ between the dietary treatments. The rabbits fed rations containing $0.3 \mathrm{~g} /$ day and $0.6 \mathrm{~g} /$ day SC recorded high intromission latency values in comparison to the control group. However, there was a significant difference in sexual behaviour between the controls and rabbits fed different levels of SC supplementation $(P>0.05)$. 


\section{EFFECT OF YEAST ON SPERM RABBITS}

Table 1 - Effect of graded levels of Saccharomyces cerevisiae (SC) on body weight in rabbits

\begin{tabular}{|c|c|c|c|}
\hline & \multicolumn{3}{|c|}{ Diet treatment (kg) } \\
\hline & $\begin{array}{c}\text { Group\#0 } \\
(n=3, \pm \text { SE) }\end{array}$ & $\begin{array}{c}\text { Group\#1 } \\
(n=3, \pm \text { SE) }\end{array}$ & $\begin{array}{c}\text { Group\#2 } \\
(n=3, \pm S E)\end{array}$ \\
\hline Day 1 & $3.335 \pm 0.23^{6}$ & $2.305 \pm 0.15^{a}$ & $3.130 \pm 0.25^{b}$ \\
\hline Day 15 & $3.303 \pm 0.25^{b}$ & $2.305 \pm 0.17^{a}$ & $3.025 \pm 0.26^{b}$ \\
\hline Day29 & $3.278 \pm 0.31^{b}$ & $2.382 \pm 0.19^{a}$ & $3.027 \pm 0.25^{b}$ \\
\hline Day 44 & $3.302 \pm 0.33^{b}$ & $2.388 \pm 0.19^{a}$ & $2.992 \pm 0.23^{b}$ \\
\hline Day 51 & $3.282 \pm 0.27^{b}$ & $2.407 \pm 0.22^{a}$ & $3.027 \pm 0.26^{b}$ \\
\hline
\end{tabular}

Table 2 - The impact of Saccharomyces cerevisiae (SC) on the haematological parameters of rabbits on different days

\begin{tabular}{|c|c|c|c|}
\hline & \multicolumn{3}{|c|}{ Diet treatment } \\
\hline & $\begin{array}{c}\text { Group\#0 } \\
(n=3, \pm \text { SE) }\end{array}$ & $\begin{array}{c}\text { Group\#1 } \\
(n=3, \pm \text { SE) }\end{array}$ & $\begin{array}{c}\text { Group\#2 } \\
\text { ( } n=3, \pm \text { SE) }\end{array}$ \\
\hline RBCs $\left(10^{6} / \mathrm{mm}^{3}\right)$ & $5.21 \pm 0.25^{a, b}$ & $6.29 \pm 0.3^{a}$ & $6.09 \pm 0.22^{b}$ \\
\hline HGB (g/dl) & $9.5 \pm 0.71^{a, b}$ & $12.9 \pm 0.58^{\mathrm{a}}$ & $12.6 \pm 0.25^{b}$ \\
\hline PLT $\left(10^{3} / \mathrm{mm}^{3}\right)$ & $352 \pm 106.7$ & $329.7 \pm 85.6$ & $281 \pm 83 . .1$ \\
\hline HCT (\%) & $28.95 \pm 1.48^{\mathrm{a}, \mathrm{b}}$ & $36.13 \pm 1.43^{a}$ & $35.97 \pm 1.1^{b}$ \\
\hline WBCs $\left(10^{3} / \mathrm{mm}^{3}\right)$ & $13.7 \pm 1.13$ & $9.9 \pm 1.61$ & $9.9 \pm 3.26$ \\
\hline LCTs $\left(10^{3} / \mathrm{mm}^{3}\right)$ & $3.75 \pm 1.34$ & $5.3 \pm 0.87$ & $4.2 \pm 1.01$ \\
\hline MCTs $\left(10^{6} / \mathrm{mm}^{3}\right)$ & $0.65 \pm 0.21$ & $1.33 \pm 0.47$ & $0.67 \pm 0.31$ \\
\hline GCTs $\left(10^{6} / \mathrm{mm}^{3}\right)$ & $9.3 \pm 2.26^{a}$ & $3.27 \pm 0.47^{a}$ & $5.07 \pm 2.94$ \\
\hline $\operatorname{MCV}(\%)$ & $53.3 \pm 3.25$ & $57.53 \pm 0.6$ & $59.17 \pm 1.62$ \\
\hline MCH (pg) & $18.35 \pm 0.07^{a, b}$ & $20.53 \pm 0.15^{a}$ & $20.7 \pm 0.79^{b}$ \\
\hline $\mathrm{MCHC}(g / d l)$ & $37.65 \pm 2.33$ & $35.73 \pm 0.55$ & $35.1 \pm 0.6$ \\
\hline RBDI (\%) & $14.85 \pm 2.05$ & $14.87 \pm 0.40$ & $15.67 \pm 0.78$ \\
\hline
\end{tabular}

Red blood cells (RBCs), haemoglobin (HGB), platelets (PLT), haematocrit (HCT), white blood cells (WBCs), lymphocytes (LCTs), monocytes (MCTs), granulocyte (GCTs), mean corpuscular volume (MCV), mean corpuscular haemoglobin ( $\mathrm{MCH})$, mean corpuscular haemoglobin concentration (MCHC), red blood cell distribution index (RBDI).

${ }^{a, b}$ Values by the same letters between the treated groups on different days are statistically different in the same row $(P<0.05)$.

The $\mathrm{pH}$ of semen seems to be stable in rabbits supplemented with $\mathrm{SC}$ and in the control group, ranging from 7.33 to 8.00 . When compared with control the group, rabbits fed diets with graded levels of SC (Group\#1 and Group\#2) had increases in mean semen volume, mass motility and individual motility at day 51 of the experiment. On the other hand, the sperm concentration was significantly lower $(P<0.05)$ in rabbits fed SC supplementation at $0.3 \mathrm{~g} /$ day and 0.6 g/day over the two months of the experiment compared to the control group. The spermatozoa mortality rate 
was lower for the rabbits fed SC supplementation at $0.3 \mathrm{~g} /$ day and 0.6 g/day (15.7\% and $11.4 \%$, respectively), compared to that in the control group $(24 \%)$.

Table 3 - Effect of graded levels of SC on scrotal diameter, sexual behaviour and sperm analysis in rabbits

\begin{tabular}{|c|c|c|c|}
\hline & \multicolumn{3}{|c|}{ Diet treatment } \\
\hline & $\begin{array}{c}\text { Group\#0 } \\
(n=3, \pm S E)\end{array}$ & $\begin{array}{c}\text { Group\#1 } \\
(n=3, \pm S E)\end{array}$ & $\begin{array}{c}\text { Group\#2 } \\
(n=3, \pm S E)\end{array}$ \\
\hline \multicolumn{4}{|l|}{ Scrotal diameter ( $\mathrm{mm})$} \\
\hline Day 15 & $5.00 \pm 0.30$ & $5.67 \pm 1.03$ & $4.82 \pm 0.72$ \\
\hline Day 45 & $5.45 \pm 0.60$ & $5.98 \pm 0.71$ & $5.55 \pm 1.14$ \\
\hline \multicolumn{4}{|l|}{ Sexual behaviour } \\
\hline Mounting latency (sec) & $5.0 \pm 3.0$ & $5.0 \pm 2.8$ & $11 \pm 2.83$ \\
\hline Intromission latency (sec) & $5.33 \pm 4.5$ & $13.00 \pm 2.8$ & $21.7 \pm 18.5$ \\
\hline \multicolumn{4}{|l|}{ Sperm analysis } \\
\hline \multicolumn{4}{|l|}{$\mathrm{pH}$} \\
\hline Day 21 & $7.33 \pm 0.06$ & $7.33 \pm 0.58$ & $7.50 \pm 0.50$ \\
\hline Day 51 & $8.00 \pm 0.00$ & $7.47 \pm 0.50$ & $8.00 \pm 0.00$ \\
\hline \multicolumn{4}{|l|}{ Semen volume $(\mathrm{ml})$} \\
\hline Day 21 & $0.67 \pm 0.06$ & $0.53 \pm 0.12$ & $0.43 \pm 0.15$ \\
\hline Day 51 & $0.40 \pm 0.00$ & $0.47 \pm 0.29$ & $0.67 \pm 0.00$ \\
\hline \multicolumn{4}{|l|}{ Mass motility } \\
\hline Day 21 & $2.67 \pm 1.53^{*}$ & $4.33 \pm 0.58$ & $6.00 \pm 1.00^{*}$ \\
\hline Day 51 & $5.00 \pm 0.00$ & $5.33 \pm 3.51$ & $6.67 \pm 0.58$ \\
\hline \multicolumn{4}{|l|}{ Individual motility } \\
\hline Day 21 & $2.00 \pm 1.73$ & $1.67 \pm 1.15^{*}$ & $4.00 \pm 0.00^{*}$ \\
\hline Day 51 & $2.00 \pm 0.00$ & $2.67 \pm 1.53$ & $4.00 \pm 0.00$ \\
\hline $\begin{array}{l}\text { Sperm } \\
\left(10^{6} / \mathrm{ml}\right)\end{array}$ & & & \\
\hline Day 21 & $269.3 \pm 122.5^{*}$ & $52.9 \pm 38.9^{*}$ & $206.3 \pm 173.6$ \\
\hline Day 51 & $390.0 \pm 0.0$ & $148.3 \pm 51.3$ & $259.4 \pm 81.1$ \\
\hline \multicolumn{4}{|l|}{$\begin{array}{l}\text { Mortality of spermatozoa } \\
(\%)\end{array}$} \\
\hline Day 21 & $43.3 \pm 15.3$ & $39.3 \pm 4.6$ & $25.3 \pm 13.0$ \\
\hline Day 51 & $24.0 \pm 0.0$ & $15.7 \pm 9.1$ & $11.0 \pm 6.9$ \\
\hline
\end{tabular}

${ }^{*}$ Values by asterisks between the treated groups on different days are statistically different in the same row $(P<0.05)$.

\section{DISCUSSION}

The present study was to investigate the effects of inclusion of the yeast $\mathrm{SC}$ in the diet on the haematological and sperm parameters of rabbits. According to the results of this study, the body weight gain of rabbits was not significantly affected by dietary SC supplementation. This confirmed the previous findings of several studies, which noted no 


\section{EFFECT OF YEAST ON SPERM RABBITS}

significant differences in the growth performance of rabbits fed a ration containing SC supplementation (Kimsé et al., 2008; Brümmer et al., 2010; Darwish et al., 2011; Seyidoglu et al., 2013; Seyidoglu and Galip, 2014; Belhassen et al., 2016). Kimsé et al. (2012) noted that yeast did not affect final body weight, daily weight gain or feed intake in New Zealand rabbits. Another study reported that the administration of SC to mice showed an insignificant improvement in growth performance (Abdel-Aziz et al., 2010). On the one hand, these different results may be due to the dose or kind of yeast used, strain of broilers, basal diet, and environmental conditions or refer to the mechanisms of growth promotion of yeast culture in rabbits, whereas generally, the positive relationship between $\mathrm{SC}$ and animal performance characteristics have been reported by several authors (Omat et al., 2010; Saied et al., 2011; Abou ElNaga et al., 2012; Ezma et al., 2012; Onwurah and Okejim, 2014, Mohamed et al., 2015). On the other hand, Onifade and Babatunde (1996) reported that a diet supplemented with $\mathrm{SC}$ at $6.0 \mathrm{~g} / \mathrm{kg}$ improved the feed quality in broiler chicks. Likewise, Waché et al. (2006) observed that the addition of SC can enhance diet and protein digestibility, which revealed better growth and food efficiency with yeast supplements. Moreover, Mohammadi et al. (2016) confirmed that using a $2 \%$ concentration of yeast in the diet improved growth and food utilization in three spots cichlid (Cichlasoma trimaculatum). The divergence of yeast results on weight gain could be due to the age of the rabbit, livestock conditions, type of feed, and type and dose of yeast incorporated into the food (Akpa et al., 2012).

Data are presented in Table 2 and demonstrate that the RBCs, HGB, HCT, GCT and MCV were significantly different in rabbits receiving graded $\mathrm{SC}$ diets as compared to the control group. This is in divergence with the previous results revealing that the use of SC in the diets of rabbits had no effect on some haematological parameters (Seyidoglu and Galip, 2014; Belhassen et al., 2016). Seyidoglu et al. (2013) revealed no significant variations in haematological parameters in treatment groups, although they noted a slight rise in haematocrit and haemoglobin concentrations in rabbits supplemented with yeast. Other findings are supported by researchers where the values of HGB, HCT, $\mathrm{RBCs}, \mathrm{MCV}, \mathrm{MCH}$ and $\mathrm{MCHC}$ were unchanged in broiler chicks fed diets containing probiotics (Gheisari et al., 2008; Shareef et al., 2009; Saied et al., 2011). Moreover, Onifade et al. (1999) noted that HCT, HGB, MCV and $\mathrm{MCH}$ rose significantly $(P<0.05)$ in rabbits receiving SC supplementation. In another investigation, Paryad et al. (2008) observed that the addition of both $1.5 \%$ and $2 \% \quad \mathrm{SC}$ yeast significantly elevated WBCs and decreased the LCT ratios of chicks. Moreover, Mulatu et al. (2019) revealed that WBCs, packed cell volume (PCV) and HGB were higher in chickens fed a diet containing SC. In addition, Saied et al. (2011) showed that dietary yeast has no effects on the 
PCV values of broiler chickens. However, Elghandour et al. (2019) observed that yeast-fed rabbits had more WBCs and LCTs, compared to the rabbited fed the control diet. It is noted that the LCT content may be a signal of improvement of humoral immune responses in rabbits fed diets supplemented with SC. Also, a relationship between dietary levels of $\mathrm{SC}$ and haematological parameters has been reported, and it could be a promoter of supplemental yeast in rabbits (Onifade et al., 1999). Likewise, our results show that SC does not affect animal health. This was demonstrated by Krzysztof et al. (2012), who observed that probiotics have immunostimulatory effects.

The results of our present study were in agreement with those of Sharawy et al. (2015), who reported a non-significant increase in testicular volume in the probiotics group, compared to that in the non-treated groups, while other researchers noted that scrotal circumference in rams was significantly greater in the probiotics fed group than in the control group (Fernandez et al., 2004; Kerban, 2008). Moreover, Kheradmand et al. (2006) indicated that both the testicular size and scrotal circumference of rams were influenced by alimentation, and the scrotal circumference was greater in the treated groups than in the control group. This result can be explained by testicular growth being associated with the nutritional value of food. The present study revealed significant differences in the sperm analysis, namely, mass motility, individual sperm motility and sperm concentration $(P<0.05)$ and were similar to those seen in rams (Sharawy et al., 2015). This result is in accordance with Emmanuel et al. (2019) and Helal et al. (2018), who observed remarkable enhancement in the sperm concentration and motility of rabbit bucks, which were supplemented with SC. These results are in agreement with results obtained previously, which recorded that the ingestion of probiotics might be recommended to improve sperm motility in human males (Valcarce et al., 2017). The antioxidant activity of SC may be the key to improvement in the sperm parameters (Uskova and Kravchenko, 2009; Spyropoulos et al., 2011; Ewuola, 2013; Mymrin et al., 2017; Shehu et al., 2016). It has been reported that yeasts and their extracts are sources of natural antioxidant cmpounds (Nishino and Ishikawa, 1998; Gazi et al., 2001).

Our results are similar to those obtained by Helal et al. (2018), who reported insignificant differences in dead spermatozoa in the experimental groups $(P>0.05)$, while the lowest proportions of dead spermatozoa were recorded in the SC groups. Nevertheless, studies claim that compounds with antioxidant properties, such as SC, have the potential to inhibit oxidative damage in the cell membranes of sperm cells and fragmentation of sperm DNA caused by free radicals (Castellini, 2008; Mourvaki et al., 2010). Our study showed an insignificant difference $(P>0.05)$ in semen $\mathrm{pH}$ values in rabbits fed dietary inclusions 


\section{EFFECT OF YEAST ON SPERM RABBITS}

of SC. However, Emmanuel et al. (2019) showed a significant reduction in the $\mathrm{pH}$ of rabbits on a SC diet. Then, the $\mathrm{pH}$ in spermatozoa plays a principal role in regulating sperm motility and fertility competence (Holm et al., 1998).

Generally, both mount and intromission latencies were used as indicators of sexual motivation (Dabhakar and Zade, 2013; Nchegang et al., 2016). The effect of the addition of $\mathrm{SC}$ on male sexual capability measured by sexual behaviours, such as mounting and intromission latencies, were insignificant $(P>0.05)$, compared to controls. Helal et al. (2018) showed identical observations, with SC having a non-significant effect on the libido of rabbits. In another investigation, the mount and intromission latencies of the Monsonia angustifolia extract-treated groups showed insignificant differences compared to the control group (Gerda Fouche et al., 2015).

\section{CONCLUSION}

The results of the present study showed that inclusion of $\mathrm{SC}$ in the diets of rabbits containing $0.3 \mathrm{~g} /$ day and $0.6 \mathrm{~g} /$ day have positive effects on the body weight and semen analysis of rabbits. Moreover, it increases the levels of some haematological parameters, such as RBCs, HGB, HCT and GCTs. More investigations are desired to document the benefits of dietary inclusion of $\mathrm{SC}$ required in rabbits under diverse environmental conditions using an appropriate number of animal experimental units.

\section{REFERENCES}

Ahmed, M.E., Abbas, T.E., Abdlhag, M.A. \& Mukhtar, D.E. (2015). Effect of dietary yeast (Saccharomyces cerevisiae) supplementation on performance, carcass characteristics and some metabolic responses of broilers. Anim. Vet. Sci., 3(5): 5-10, DOI: $\quad 10.11648 /$ j.avs.s.201503050 1.12

Arif, M., Iram, A., Bhutta, M.A.K., Naiel, M.A.E., Abd El-Hack, M.E., Othman, S.I...\& Taha, A.E. (2020). The biodegradation role of Saccharomyces cerevisiae against harmful effects of mycotoxin contaminated diets on broiler performance, immunity status, and carcasscharacteristics. Animals, 10(2): 238, DOI: 10.3390/ani1002 0238

Belhassen, T., Bonai, A., Gerencsér, Z., Matics, Z., Tuboly, T., Bergaoui, R. \& Kovacs, M. (2016). Effect of diet supplementation with live yeast Saccharomyces cerevisiae on growth performance, caecal ecosystem and health of growing rabbits. World Rabbit Sci., 24(3): 191, DOI: 10.4995/wrs.2016.3991

Castanon, J.I.R. (2007). History of the use of antibiotic as growth promoters in European poultry feeds. Poultry Sci., 86(11): 2466-2471, DOI: 10.3382/ps.2007-00249

Cha, J.-Y., Heo, J.-S., Park, B.-K. \& Cho, Y.-S. (2008). Effect of zinc-enriched yeast supplementation on serum zinc and testosterone concentrations in ethanol feeding rats. J. Life Sci., 18(7): 947-951, DOI: $10.5352 / j l s .20$ 08.18.7.947

Elghandour, M.M.Y., Tan, Z.L., Abu Hafsa, S.H., Adegbeye, M.J., Greiner, R., Ugbogu, E.A. ...\& Salem, A.Z.M. (2019). Saccharomyces cerevisiaeas a probiotic feed additive to non and pseudo-ruminant feeding: a review. $J$. Appl. Microbiol., 128(3): 658-674, DOI: $10.1111 / \mathrm{jam} .14416$ 
Emmanuel, D., Amaka, A., Okezie, E., Sunday, U. \& Ethelbert, O. (2019). Epididymal sperm characteristics, testicular morphometric traits and growth parameters of rabbit bucks fed dietary Saccharomyces cerevisiae and/or zinc oxide. Rev. Bras. Cienc. Avic., 21(1), DOI: 10.1590/1806-9061-2018-0803

Esteso, M.C. (2006). Functional significance of the sperm head morphometric size and shape for determining freezability in Iberian Red Deer (Cervus elaphus hispanicus) epididymal sperm samples. J. Androl., 27(5): 662-670, DOI: $10.2164 /$ jandrol.106.000489

Ezema, C. \& Eze, D.C. (2010). Determination of the effect of probiotic (Saccharomyces cerevisiae) on growth performance and hematological parameters of rabbits. Com. Clin. Path., 21(1): 73-76, DOI: 10.1007/s00580-010-1066-6

Fernández, M., Giráldez, F., Frutos, P., Lavín, P. \& Mantecón, A. (2004). Effect of undegradable protein supply on testicular size, spermiogram parameters and sexual behavior of mature Assaf rams. Theriogenology, 62(1-2): 299-310, DOI: 10.1016/j.theriogenology.2003. 10.003

Fouche, G., Afolayan, A.J., Wintola, O.A., Khorombi, T.E. \& Senabe, J. (2015). Effect of the aqueous extract of the aerial parts of Monsonia angustifolia E. Mey. Ex A. Rich., on the sexual behaviour of male Wistar rats. BMC Complement. Altern. Med., 15(1): DOI: 10.1186/s12906-0150880-4

France, 29-30 November (2005). Abstracts of the 11èmes Journées de la Recherche Cunicole. World Rabbit Sci., 14(sp): 35-50, DOI: 10.4995/wrs.2006.536

Helal, F., El- Badawi, A., Abou-ward, G., El-Naggar, S., Hassan, A., Basyoney, M. \& Morad, A. (2018). Semen quality parameters of adult male NZW rabbits fed diets added with two different types of probiotics. Egypt. J. Nutr. Feeds, 21(1): 125132, DOI: 10.21608/ejnf.2018.75423

Higginbotham, G.E. \& Bath, D.L. (1993). Evaluation of Lactobacillus fermentation cultures in calf feeding systems. J. Dairy Sci., 76(2): 615620, DOI: 10.3168/jds.s0022-0302 (93) $77382-8$

Holm, L. \& Wishart, G.J. (1998). The effect of $\mathrm{pH}$ on the motility of spermatozoa from chicken, turkey and quail. Anim. Reprod. Sci., 54(1): 45-54, DOI: 10.1016/s0378-4320 (98)00142-0

Kimsé, M., Bayourthe, C., Monteils, V., Fortun-Lamothe, L., Cauquil, L., Combes, S. \& Gidenne, T. (2012). Live yeast stability in rabbit digestive tract: Consequences on the caecal ecosystem, digestion, growth and digestive health. Anim. Feed Sci. Technol., 173(3-4): 235-243, DOI: 10.1016/j.anifeedsci.2012.01.012

Kimsé, M., Bayourthe, C., Monteils, V., Fortun-Lamothe, L., Cauquil, L., Combes, S. \& Gidenne, T. (2012). Live yeast stability in rabbit digestive tract: Consequences on the caecal ecosystem, digestion, growth and digestive health. Anim. Feed Sci. Technol., 173(3-4): 235-243. DOI: 10.1016/j.anifeedsci.2012.01.012

Kinoshita, M., Hori, N., Aida, K., Sugawara, T. \& Ohnishi, M. (2007). Prevention of melanin formation by yeast cerebroside in B16 mouse melanoma cells. J. Oleo Sci., 56(12): 645-648, DOI: 10.5650/jos.56.645

Lee, S., Kim, W.-G., Kim, E., Ryoo, I.-J., Lee, H. K., Kim, J. N. ... \& Yoo, I.-D. (2005). Synthesis and melanin biosynthesis inhibitory activity of $( \pm)$ terrein produced by Penicillium $s p$. 20135. Bioorg. Med. Chem. Lett., 15(2): 471-473, DOI: 10.1016/j.bmcl. 2004.10.057

Mourvaki, E., Cardinali, R., Dal Bosco, A., Corazzi, L. \& Castellini, C. (2010). Effects of flaxseed dietary 


\section{EFFECT OF YEAST ON SPERM RABBITS}

supplementation on sperm quality and on lipid composition of sperm subfractions and prostatic granules in rabbit. Theriogenology, 73(5): 629637, DOI: 10.1016/j.theriogenology. 2009.10.019

Mulatu, K., Ameha, N. \& Girma, M. (2019). Effects of feeding different levels of baker's yeast on performance and hematological parameters in broiler chickens. J. World's Poult. Res., 9(2): 38-49, DOI: 10.36380/jw pr.2019.5

Mutwedu, V.B., Ayagirwe, R.B.B., Bacigale, S.B., Mwema, L.M., Butseme, S., Kashosi, T. ... \& Nyongesa, A.W. (2019). Effect of dietary inclusion of small quantities of Mucuna pruriens seed meal on sexual behavior, semen characteristics, and biochemical parameters in rabbit bucks (Oryctolagus cuniculus). Trop. Anim. Health Prod., 51(5): 1195-1202, DOI: 10.1007/s11250-019-01808-2

Nada, S.A., Amra, H.A., Abdel-Aziz, K.B., Omara, E.A., Farag, I.M., Tawfek, N.S. \& Darwish, H.R. (2011). Saccharomyces cereviciae potentially inhibit ochratoxicosis in male albino mice. Toxicol. Lett., 205: S143-S144, DOI: 10.1016/j.toxlet. 2011.05.509

Nchegang, B., Mezui, C., Longo, F., Nkwengoua, Z.E., Amang, A.P. \& Tan, P.V. (2016). Effects of the aqueous extract of Eremomastax speciosa (Acanthaceae) on sexual behavior in normal male rats. BioMed. Res. Int., 1-10, DOI: 10.1155/2016/9706429

Ogunade, I.M., Lay, J., Andries, K., McManus, C.J. \& Bebe, F. (2019). Effects of live yeast on differential genetic and functional attributes of rumen microbiota in beef cattle. J. Anim. Sci. Biotechnol., 10(1), DOI: 10.1186/s40104-019-0378-x

Onifade, A.A. \& Babatunde, G.M. (1996). Supplemental value of dried yeast in a high-fibre diet for broiler chicks. Anim. Feed Sci. Technol., 62(2-4): 91-96, DOI: 10.1016/s0377-8401 (96)00991-1
Onifade, A., Obiyan, R., Onipede, E., Adejumo, D., Abu, O...\& Babatunde, G. (1999). Assessment of the effects of supplementing rabbit diets with a culture of Saccharomyces cerevisiae using growth performance, blood composition and clinical enzyme activities. Anim. Feed Sci. Technol., 77(1-2): 25-32, DOI: 10.1016/s03778401(98)00244-2

Pinheiro, R.E.E., Rodrigues, A.M.D., Lima, C.E., Santos, J.T.O., Pereyra, C.M., Torres, A. M...\& Muratori, M.C.S. (2020). Saccharomyces cerevisiae as a probiotic agent and a possible aflatoxin B1 adsorbent in simulated fish intestinal tract conditions. Arq. Bras. Med. Vet. Zootec., 72(3): 862-870, DOI: 10.1590/1678-4162-11280

Saied, J.M., Al-Jabary, Q.H. \& Thalij, K.M. (2011). Effect of dietary supplement yeast culture on production performance and hematological parameters in broiler chicks. Int. J. Poult. Sci., 10(5): 376380, DOI: 10.3923/ijps.2011.376.380

Sanna, F., Contini, A., Melis, M.R. \& Argiolas, A. (2015). Role of dopamine D4 receptors in copulatory behavior: Studies with selective D4 agonists and antagonists in male rats. Pharmacol. Biochem. Behav., 137, 110-118, DOI: 10.1016/j.pbb. 2015.08.012

Seyidoğlu, N., Galip, N. \& Sonat, F.A. (2014). Effect of yeast culture on growth performance, haematological and biochemical indices of $\mathrm{New}$ Zealand white rabbits. Uludağ Üniv. Vet. Fak. Derg., 32(2): 11-18, DOI: 10.30782/uluvfd.163480

Seyidoğlu, N. \& Galip, N. (2014). Effects of Saccharomyces cerevisiae and Spirulina platensis on growth performances and biochemical parameters in rabbits. Kafkas Üniv. Vet. Fak. Derg., 20(3): 331-336, DOI: 10.9775/kvfd.2013.9988

Shehu, B.M., Ayanwale, B.A., Ayo, J.O. \& Uchendu, C. (2016). Short communication: Effect of 


\section{Omar BESSEBOUA, Abdelhanine AYAD}

Saccharomyces cerevisiae supplementation on some biomarkers of oxidative stress in weaned rabbits during the hot-dry season. World Rabbit Sci., 24(1): 67-70, DOI: 10.4995/wrs.2016.1656

Spyropoulos, B.G., Misiakos, E.P., Fotiadis, C. \& Stoidis, C.N. (2010). Antioxidant properties of probiotics and their protective effects in the pathogenesis of radiation-induced enteritis and colitis. Dig. Dis. Sci., 56(2): 285-294, DOI: 10.1007/s10 620-010-1307-1

Valcarce, D.G., Genovés, S., Riesco, M.F., Martorell, P., Herráez, M.P., Ramón, D. \& Robles, V. (2017).
Probiotic administration improves sperm quality in asthenozoospermic human donors. Benef. Microbes, 8(2): 193-206, DOI: 10.3920/bm20 16.0122

Waché, Y., Auffray, F., Gatesoupe, F.-J., Zambonino, J., Gayet, V., Labbé, L. \& Quentel, C. (2006). Cross effects of the strain of dietary Saccharomyces cerevisiae and rearing conditions on the onset of intestinal microbiota and digestive enzymes in rainbow trout, Onchorhynchus mykiss, fry. Aquaculture, 258(1-4): 470-478, DOI: 1016/j.aquaculture.2006.04. 002 